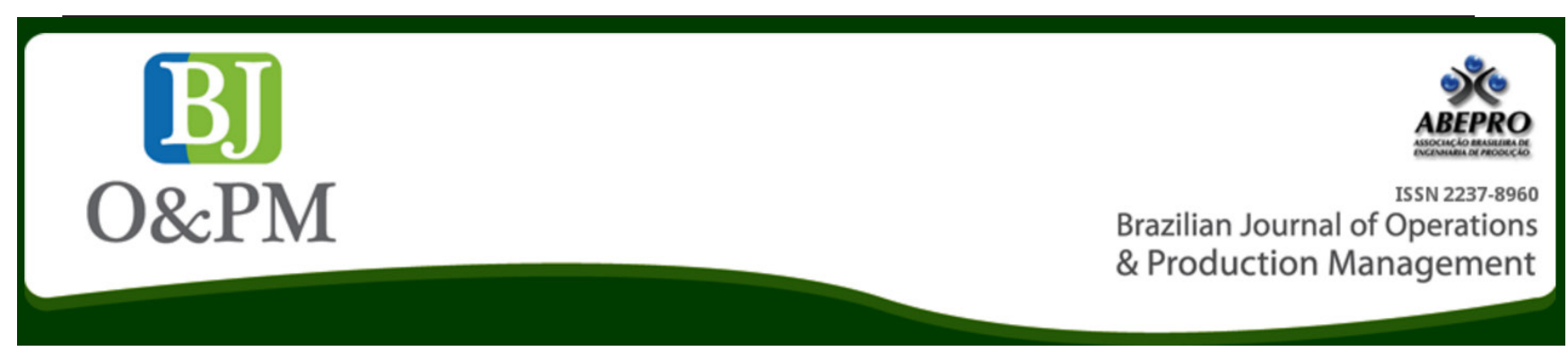

\title{
DIAGNOSIS FOR THE IMPLEMENTATION OF AN ENVIRONMENTAL MANAGEMENT SYSTEM IN MICROBUSINESS IN THE URBAN VECTOR AND PEST CONTROL SECTOR
}

\author{
Renata Maciel Ribeiroa; Sergio Ricardo Barros ${ }^{a}$; Julio Cesar Wassermana; JBarbara Franz ${ }^{\mathrm{a}}$ \\ ${ }^{\text {a }}$ Federal Fluminense University (UFF) - Niterói, RJ, Brazil
}

\section{Abstract}

This project analyzes and discusses the application of a methodological valuation model of an environmental maturity of a company of vectors and pests control. The method used was the initial environmental diagnostics, which intended to classify in a scale of values the Business Process of the company to Certification based on NBR ISO 14001. As a result of the application of the method were identified EMS Critical Success Spots low performed by the company, and the positive influence of ISO 9001 Certification already established in the organization. As well as proposed actions to improve the weaknesses that were identified by the diagnostics in order to establish a schedule for the compliance of the first phase of the PDCA method proposed by the ISO 14001.

Keywords: Environmental Management System. Environmental Diagnostics.Vectors and Pests Control. ISO 14001.

\section{INTRODUCTION}

The company studied in this paper, after understanding the need for changes resulting from the construction of the Petrochemical Complex in the municipality of Itaboraí, which belongs to the state of Rio de Janeiro, began the process of implementing the Quality Management System (QMS) that provided the ISO 9001 certification to its business processes in 2013. The QMS can be defined as a company's established quality standard to achieve more efficient processes and customer satisfaction (MAEKAWA, 2013).

All the experiences gained in the implementation of QMS (Quality Management System), for example, the systematization and organization of inputs and outputs to meet the company standard required by ISO, led high administration to understand that quality in service provision also covers environmental variables within in the activity.

From this demand began the process of implementing the Environmental Management System, which follows the company's environmental assessment, where all areas audited by ISO 14001, will be analyzed and evaluated for relevance of impact and possible forms of mitigation and or compensation. The fact that the company already has ISO 9001 facilitated the EMS implementation process, because it establishes well-founded strategies for compliance with ISO 14001 requirements.

The object of the study in question is an urban vector and pests control company, which requires attention regarding environmental responsibility, as it falls into IBAMA'S potentially polluting activities table, in the "utility services" section, item 17-15 ( provision of household pests control service with the application of chemicals) (IBAMA, 2014). This makes the environmental issue a constant concern for the company to keep itself healthy and within the standards required by regulators.

Demand for the research appeared when the studied company signaled the need to implement an EMS for the certification of its processes in concern about the aspects and impacts on the environment. As a way to meet this primary objective, the environmental assessment provides an overview of the environmental maturity of the company to achieve ISO 14001 certification, since the areas analyzed by the diagnosis are the same audited by the ISO 9001 certification.

To this end, a general objective was established to apply an environmental assessment model to determine the 
degree of organizational maturity for future certification based on NBR ISO 14001 Norm.

To assist in successfully reaching the overall goal, the following objectives were established:

a) Evaluate the critical success factors in business processes, using the model of the Initial Diagnosis EMS;

b) Propose improvement actions for any critical factors found.

\section{METHODOLOGY}

Initially, business scenarios were planned seeking to identify and analyze the SGA requirements, determine the existing elements in the QMS, develop procedures for items not covered by the QMS and finally, implement and verify the EMS (BLOCK, 2000).
The analysis method used is based on a multi-criteria matrix, consisting of a set of methods and techniques to assist or support people and organizations in decision making under the influence of a plurality of criteria (Gomes, 2002), established by AVALIAMB (Diagnostic Evaluation of the Environmental Management System) developed by Barros et Wasserman (2009) based on La Rovere (2001) and Freitas (2001). Since the matrix is based on key areas and processes evaluated in an audit for compliance with the ISO 14001 (Table 1), it covers all the items appraised by the norm and presents through its results the degree of adequacy of each item to implement in the parameters proposed by ISO. Each of the subjects assessed by diagnosis (Table 1) are detailed in its particularity in the analysis form proposed by the diagnosis as a more thorough way of evaluating each item, and applied to the representatives in the administrative and operational areas of the company.

Table 1 - Area planning and processes evaluated by environmental management auditing.

\begin{tabular}{|l|}
\hline ITEMS OF MANAGEMENT SYSTEM \\
\hline ENVIRONMENTAL POLICY \\
\hline LEGAL AND CORPORATE REQUIREMENTS \\
\hline SPECIFIC ENVIRONMENTAL ASPECTS \\
\hline OBJECTIVES AND GOALS \\
\hline ENVIRONMENTAL MANAGEMENT PROGRAM \\
\hline ORGANIZATIONAL STRUCTURE AND RESPONSIBILITY \\
\hline AWARENESS AND TRAINING \\
\hline COMMUNICATION \\
\hline ENVIRONMENTAL MANAGEMENT SYSTEM DOCUMENTATION \\
\hline DOCUMENTATION CONTROL \\
\hline OPERATIONAL CONTROL \\
\hline EnergY consumption \\
\hline Transport and Distribution \\
\hline Water consumption \\
\hline Sanitary Sewage and Rainwater \\
\hline Industrial Effluents \\
\hline Waste Management \\
\hline Waste carriers and receivers \\
\hline Air Emission Management \\
\hline Noise \\
\hline Materials Management \\
\hline Production and Operating Processes \\
\hline Hygiene and Health \\
\hline
\end{tabular}




\begin{tabular}{|l|}
\hline EMERGENCY SITUATIONS \\
\hline MONITORING AND EVALUATION \\
\hline PREVENTIVE AND CORRECTIVE ACTIONS \\
\hline INTERNAL AUDIT \\
\hline ENVIRONMENTAL MANAGEMENT SYSTEM REVIEW \\
\hline
\end{tabular}

Source: AVALIAMB (BARROS et WASSERMAN, 2009).

In the initial environmental diagnosis each presented item is individually evaluated by representatives chosen to participate in the study, which assign a score of 0 (zero) to
4 to assess the adequacy of the company to the proposed theme (Table 2).

Table 2 - Established criteria for the assessment of environmental management areas and processes.

EVALUATION OF ENVIRONMENTAL MANAGEMENT SYSTEM DIAGNOSIS - AVALIAMB

\section{Instructions}

The questionnaire assesses 16 environmental management requirements. For each requirement there are questions which should be evaluated from 0 to 4 according to the following criteria:

\begin{tabular}{|l|l|}
\hline 0 & No, this enterprise does not carry out any action or verification in this regard. \\
\hline 1 & No, but intends to implement or verify. \\
\hline 2 & Yes, but this situation is not formalized. \\
\hline 3 & Yes, it is in formal implementation phase. \\
\hline 4 & Yes, it is implemented and compliant. \\
\hline
\end{tabular}

Source: AVALIAMB (BARROS et WASSERMAN, 2009).

After evaluating each item individually (Table 1), the subgroup gets a percentage of adequacy ranging from $0 \%$ to $100 \%$ (Table 3 ), the closer to $100 \%$, the higher its degree of compliance with the standard on the subject proposed. This percentage represents how much the company needs to work to comply with the requirements of NBR ISO 14001.

Table 3 - Example of the company's adequacy percentages to some items proposed by the diagnosis.

\begin{tabular}{|l|c|}
\hline ENVIRONMENTAL POLICY & $38 \%$ \\
\hline LEGAL AND CORPORATE REQUIREMENTS & $76 \%$ \\
\hline SPECIFIC ENVIRONMENTAL ASPECTS & $33 \%$ \\
\hline OBJECTIVES AND GOALS & $45 \%$ \\
\hline ENVIRONMENTAL MANAGEMENT PROGRAM & $21 \%$ \\
\hline ORGANIZATIONAL STRUCTURE AND RESPONSIBILITY & $75 \%$ \\
\hline AWARENESS AND TRAINING & $71 \%$ \\
\hline COMMUNICATION & $48 \%$ \\
\hline
\end{tabular}

Source: AVALIAMB (BARROS et WASSERMAN, 2009).

The results in percentage obtained for each item, when added in their total among all the items evaluated, generates a score from 0 (zero) to 5 points, according to (Table 4). This score is the main indicator of the degree of environmental maturity of the company for the implementation of an EMS and future ISO 14001 certification. 
Table 4 - Score variation obtained through the diagnosis and notes regarding the level of environmental maturity of the company.

Between 0 and 1.9 points: the environmental manage-
ment of the project does not have proper balance (is
vulnerable); some requirements can be developed while
others are fragile.
Between 2 and 3.9 points: the project is on track for EMS
certification, but still has a long way to go.
Between 4 and 5 points: the enterprise has an Envi-
ronmental Management System that may be close to
conformity regarding ISO 14001 requirements and, con-
sequently, the environmental certification system.

Source: AVALIAMB (BARROS et WASSERMAN, 2009).

As a way of collecting and processing data, the diagnosis was applied and from the results improvement actions were proposed for the weaknesses identified by the matrix. From the model results, it is expected that a strategic plan of action is established to prepare the company for future the implementation of an Environmental Management System.

As the chosen methodology for application and model analysis, the environmental assessment form was applied to a representative of the administrative department, which participates fully in the business management and knows all the activities developed by the company. This diagnosis will be the main basis for the development of responses to the objectives proposed by the study. The results obtained will be analyzed and from this preliminary assessment, the actions will be proposed for improvements in the Critical Success Factors (CSFs) indicated by the result of the diagnosis. In order to promote the counterpoint of opinions and perceptions, the same form was applied to a representative of the operational department, which will be demonstrated and evaluated on differences and similarities with the diagnosis applied to the representative of the administrative sector. From the results obtained, the underperforming Critical Success Factors in the EMS will be identified.

The model adopted as criteria for establishing the CSFs that: the items assessed (Table 1) with smaller adequacy percentages than $70 \%$ (Table 3) are considered Critical Success Factors for the EMS and should be evaluated and dealt actions for the nonconformities. For items with equal or higher percentage than $70 \%$, which is the score that falls between 4 and 5 points (Table 4) and means that the item conforms to the standard NBR ISO 14001. It is assessed that these are in the process of adaptation and will require little work or for their suitability, but those who presented adequacy percentages lower than $70 \%$ fall in the range between 0 and 3.9 points (Table 4) and require greater efforts targeted to actions for adjustment and correction of the items in the requirements of the norm.

\section{RESULTS}

From the results shown by the diagnosis matrix applied to the representative of the administrative department (Table 5) and adopting the above criteria, areas that obtained a percentage of less capacity than $70 \%$ were identified as Critical Success Factors. The color gradient in the matrix (Table 5) indicates the degree of maturity of the item evaluated in the EMS company. In the variation between "dark gray" and "white", the first means higher degree of nonconformity and the second means greater degree of conformity with the norm.

Table 5 - Results of diagnosis applied to the representative of the administrative department.

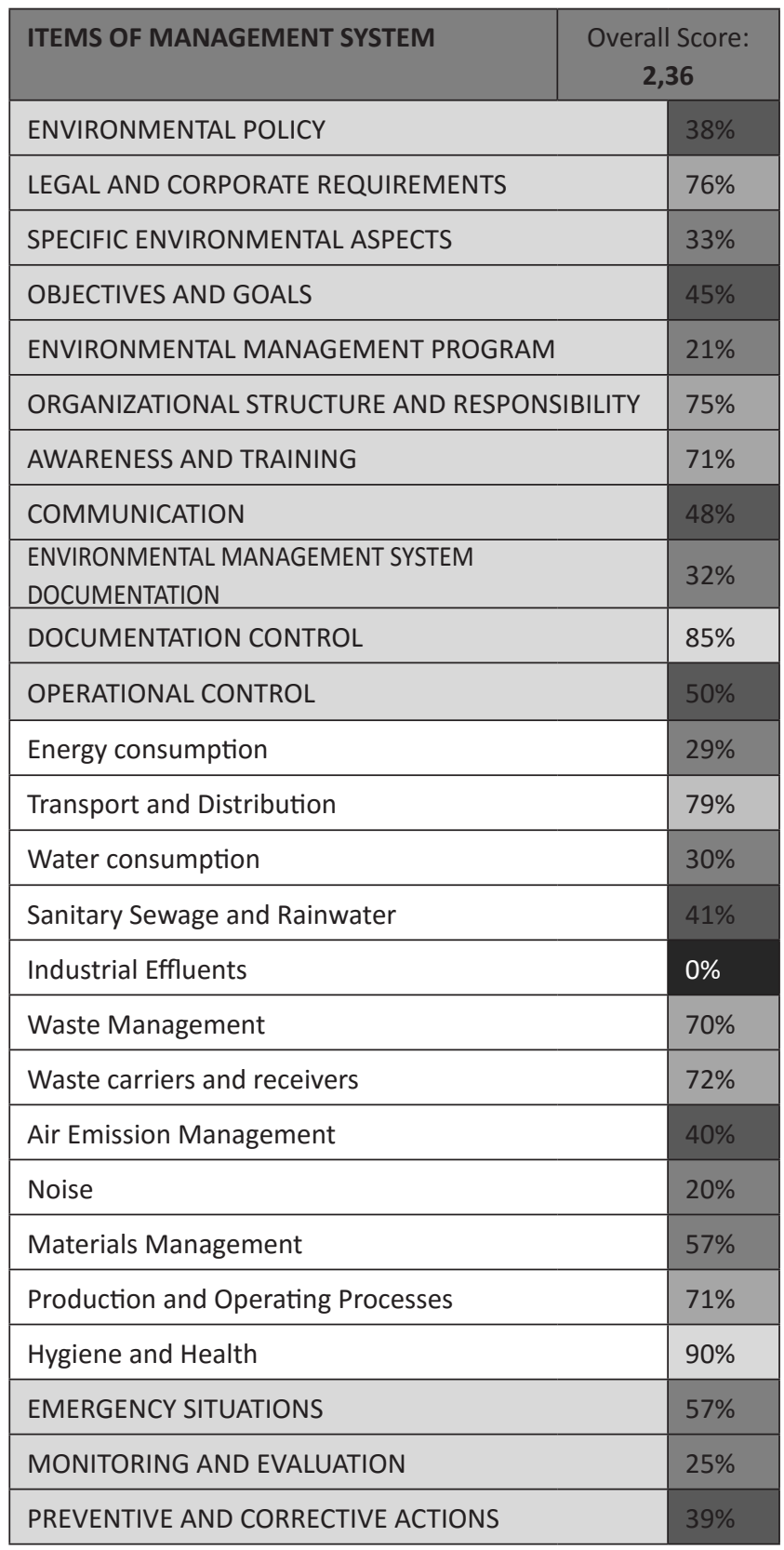




\begin{tabular}{|l|l|}
\hline INTERNAL AUDIT & $33 \%$ \\
\hline ENVIRONMENTAL MANAGEMENT SYSTEM REVIEW & $25 \%$ \\
\hline
\end{tabular}

Source: AVALIAMB (Barros et Wasserman, 2009).

The observation and analysis of the situation identifies the company's degree of maturity for the implementation of ISO 14001. From the results obtained, it is possible to see that the company is in the current situation of medium compliance with the standard, with the result of 2.36 points in the diagnosis applied to the representative of the administrative department, which represents that the organization's EMS is under implementation and still demands many actions to achieve compliance with the standard, presenting thus still a large number of CSFs, meaning items evaluated with an adequacy percentage of less than $70 \%$.

In the framework of analysis it is possible to identify the weaknesses in the current situation of the organization's EMS, resulting from the absence or deficiency in specific actions for the areas analyzed by the form. From this point, it is possible to reflect on these results inside and outside the company walls and try to identify common weaknesses for other business realities seeking certification in ISO 14001.

Some authors state in their research that the vast majority of Brazilian organizations have demonstrated different behaviors when it comes to environmental management (ROHRICH et CUNHA, 2004), individually presenting their CSFs according to the market profile and product linked to the activity performed.
However, the motivation behind the implementation of an EMS and inclusion of the environmental variable in business processes is linked to a single purpose: "The concern to conform to the rules and regulations dictated by the environment that would thereby originate uniformity in organizations" (ALPERSTEDTET et al., 2010). This institutional isomorphism (ZUCKER, 1987) would be responsible for this homogeneity of purposes from corporate environmental management. However, it must be questioned, given the territorial insertions of each organization.

The consistent motivations and results of differing maturity between organizations lead to a reflection about what causes this discrepancy between motivation and the weaknesses pointed out by an environmental diagnosis, or another method of evaluating the EMS. Machado da Silva et al., (1999) pointed out that these results originate mainly in the social context in which the company operates and its relationship and interests with an environmental image that is proposed. To supplement this statement form, it is possible to realize the importance of an effective participation of the environmental professional in the areas of enterprise management system and the influence of this participation in the seriousness of the results highlighted by the diagnosis and actions proposed, dealing with environmental responsibility across the board in all areas and sectors covered by the organization.

The weaknesses identified through the Critical Success Factors in Table 5 are associated with justifications that have obtained through this work, proposals for improvement actions for their nonconformity (Table 6).

Table 6 - Critical Factors of Success and their respective justifications and proposals for improvement actions.

\begin{tabular}{|c|c|c|c|}
\hline $\begin{array}{c}\text { Critical Success } \\
\text { Factors }\end{array}$ & Analysis of the Main Causes & Improvement actions & Adequacy (\%) \\
\hline Environmental Policy & $\begin{array}{l}\text { The low score in this item } \\
\text { is justified by the limited } \\
\text { development of the EMS } \\
\text { implementation process, } \\
\text { where the company does } \\
\text { not have an established } \\
\text { environmental policy. }\end{array}$ & $\begin{array}{l}\text { From the weaknesses } \\
\text { identified by the diagnosis, } \\
\text { it is suggested that the } \\
\text { company hold a critical } \\
\text { analysis meeting with the } \\
\text { high administration to } \\
\text { establishtheenvironmental } \\
\text { policy aimed at prevention } \\
\text { and mitigation for } \\
\text { environmental impact. }\end{array}$ & $38 \%$ \\
\hline $\begin{array}{c}\text { Specific } \\
\text { Environmental } \\
\text { Aspects }\end{array}$ & $\begin{array}{l}\text { In this item, the low score is } \\
\text { justified for two reasons: the } \\
\text { first is that the company is } \\
\text { still in an immature stage of } \\
\text { its EMS and failing to provide } \\
\text { in a documented form its } \\
\text { potential environmental } \\
\text { aspects and impacts and; } \\
\text { the second is the fact that } \\
\text { several items in the form do } \\
\text { not apply to the reality of } \\
\text { the company. }\end{array}$ & $\begin{array}{l}\text { As an immediate action } \\
\text { proposed for this item, } \\
\text { the identification of } \\
\text { possible environmental } \\
\text { aspects of the activity and } \\
\text { development of procedures } \\
\text { is recommended, which } \\
\text { will provide control of the } \\
\text { company's possible daily } \\
\text { and accidental emissions } \\
\text { and, if necessary, establish } \\
\text { mitigating actions. }\end{array}$ & $33 \%$ \\
\hline
\end{tabular}




\begin{tabular}{|c|c|c|c|}
\hline Objectives and Goals & $\begin{array}{l}\text { The absence of an } \\
\text { established Environmental } \\
\text { Policy opens a gap in } \\
\text { planning which hinders the } \\
\text { development of various } \\
\text { areas audited by certification } \\
\text { and issues addressed by the } \\
\text { item that does not apply } \\
\text { to the company's reality } \\
\text { also affected negatively on } \\
\text { the poor score. However } \\
\text { there has been a favorable } \\
\text { scenario in the company's } \\
\text { compliance in its objectives } \\
\text { and goals established } \\
\text { with financial provision } \\
\text { for operation, goals and } \\
\text { objectives that reflect the } \\
\text { environmental aspects of } \\
\text { the activity. }\end{array}$ & $\begin{array}{l}\text { The high administration } \\
\text { should establish goals and } \\
\text { objectives for the EMS } \\
\text { collaborate to fulfill all } \\
\text { requirements addressed } \\
\text { in the company's } \\
\text { environmental policy. } \\
\text { Taking necessary care to } \\
\text { establish measurable goals } \\
\text { so that can be achieved } \\
\text { successfully. }\end{array}$ & $45 \%$ \\
\hline $\begin{array}{c}\text { Environmental } \\
\text { Management } \\
\text { Program }\end{array}$ & $\begin{array}{l}\text { In this section of the } \\
\text { diagnosis the low score is } \\
\text { justified by the immaturity of } \\
\text { the EMS, due to the fact that } \\
\text { the company doesn't have } \\
\text { the Environmental Policy or } \\
\text { established objectives and } \\
\text { goals, which creates a delay } \\
\text { in the development and } \\
\text { management planning. }\end{array}$ & $\begin{array}{l}\text { Wait for the compliance } \\
\text { with the previous stages of } \\
\text { the EMS and establish goals } \\
\text { and objectives for each } \\
\text { relevant level and function } \\
\text { in the organization, so that } \\
\text { all are integrated. }\end{array}$ & $21 \%$ \\
\hline Communication & $\begin{array}{l}\text { Deficiency in external } \\
\text { social relations and } \\
\text { immaturity in the company's } \\
\text { environmental management } \\
\text { justifies the low performance } \\
\text { of this item. For even with } \\
\text { the implemented quality } \\
\text { management system and } \\
\text { the communication item } \\
\text { also being an ISO } 9001 \\
\text { requirement, it does not } \\
\text { provide for environmental } \\
\text { issues inserted in the } \\
\text { process, like establishing } \\
\text { external communication } \\
\text { procedures with the } \\
\text { surrounding community. }\end{array}$ & $\begin{array}{l}\text { Implement an effective } \\
\mathrm{E} \mathrm{n} \text { v i } \mathrm{r} \text { o } \mathrm{n} \text { m e } \mathrm{n} \mathrm{t} \text { a I } \\
\text { Management System } \\
\text { that addresses not } \\
\text { only environmental } \\
\text { improvements in the } \\
\text { service life cycle, but also } \\
\text { in social and environmental } \\
\text { relations between the } \\
\text { company and society. }\end{array}$ & $48 \%$ \\
\hline
\end{tabular}




\begin{tabular}{|c|c|c|c|}
\hline $\begin{array}{c}\text { Environmental } \\
\text { Management System } \\
\text { Documentation }\end{array}$ & $\begin{array}{l}\text { The unsatisfactory score is } \\
\text { justified by the lack of basic } \\
\text { EMS documents as a result } \\
\text { of an immature system and } \\
\text { lack of implementation } \\
\text { of some items in relation } \\
\text { to the company's reality. } \\
\text { However, the company's } \\
\text { environmental permits are } \\
\text { updated, documented and } \\
\text { fully compliant with the } \\
\text { standard. }\end{array}$ & $\begin{array}{l}\text { Identification } \\
\text { evaluation of activities } \\
\text { carried out by the company } \\
\text { for the preparation } \\
\text { of all necessary } \\
\text { documentation for the } \\
\text { EMS implementation by } \\
\text { the high administration } \\
\text { in concurrence } \\
\text { with the company's } \\
\text { department responsible } \\
\text { for maintenance of } \\
\text { management systems. }\end{array}$ & $32 \%$ \\
\hline Operational Control & $\begin{array}{l}\text { Several areas evaluated by } \\
\text { this item of the form have } \\
\text { their low scores justified } \\
\text { by the non-applicability of } \\
\text { the item to the activities } \\
\text { performed by the company, } \\
\text { and another part has its } \\
\text { justification guided by the } \\
\text { immaturity of the EMS that } \\
\text { does not have its processes } \\
\text { appropriately mapped } \\
\text { regarding the deterioration } \\
\text { of natural resources involved } \\
\text { in the activity. }\end{array}$ & $\begin{array}{l}\text { Mapping and register of } \\
\text { the company's activity on } \\
\text { the use or depletion of } \\
\text { natural resources in order } \\
\text { to achieve the optimization } \\
\text { of activities to decrease } \\
\text { the use of raw materials } \\
\text { and consequently better } \\
\text { the economic performance } \\
\text { through the development } \\
\text { of procedures that include } \\
\text { all activities involved in the } \\
\text { business process. }\end{array}$ & $50 \%$ \\
\hline Emergency Situations & $\begin{array}{l}\text { The unsatisfactory score } \\
\text { in this item is justified } \\
\text { primarily by microenterprise } \\
\text { profile, which still has } \\
\text { its work security sector } \\
\text { linked to the operational } \\
\text { sector, which hampers } \\
\text { the specific planning for } \\
\text { emergencies. However, the } \\
\text { company complies with the } \\
\text { legal aspects of accident } \\
\text { prevention and action plan, } \\
\text { both in its training and in } \\
\text { adequate physical facilities } \\
\text { for action in emergency } \\
\text { situations. }\end{array}$ & $\begin{array}{l}\text { For a better performance } \\
\text { in emergency situations, } \\
\text { it is recommended that } \\
\text { the company elaborates } \\
\text { a procedure that maps } \\
\text { out the cause of inherent } \\
\text { risks in the activity and } \\
\text { develop a contingency plan } \\
\text { establishing methods to } \\
\text { respond to accidents which } \\
\text { are requirements of the } \\
\text { ISO } 14001 \text { and establish } \\
\text { training to maintain } \\
\text { the EMS in this specific } \\
\text { item and the work force } \\
\text { supervision to comply with } \\
\text { the standard. }\end{array}$ & $57 \%$ \\
\hline $\begin{array}{c}\text { Monitoring and } \\
\text { Evaluation }\end{array}$ & $\begin{array}{l}\text { The lack of progress in } \\
\text { operational control at the } \\
\text { heart of environmental } \\
\text { issues involved in the } \\
\text { activity entails disability } \\
\text { and a consequent low score } \\
\text { on this item, which has } \\
\text { limitation to run by a lack of } \\
\text { environmental planning in } \\
\text { the operational sector of the } \\
\text { institution. }\end{array}$ & $\begin{array}{l}\text { Promote improvements } \\
\text { for better efficiency in } \\
\text { the operating sector, } \\
\text { establishing tools } \\
\text { and indicators for } \\
\text { monitoring and assessing } \\
\text { the environmental } \\
\text { performance of the } \\
\text { company. }\end{array}$ & $25 \%$ \\
\hline
\end{tabular}




\begin{tabular}{|c|l|}
\hline $\begin{array}{c}\text { Preventive and } \\
\text { Corrective Actions }\end{array}$ & $\begin{array}{l}\text { The unsatisfactory score } \\
\text { in this regard relates to } \\
\text { the lack of mechanisms } \\
\text { for evaluation, prevention } \\
\text { and correction of non- } \\
\text { conformities related to } \\
\text { the EMS. This weakness is } \\
\text { justified by the company's } \\
\text { present situation of } \\
\text { environmental management } \\
\text { that is still undeveloped, } \\
\text { with much of their strategies } \\
\text { for managing deployed, but } \\
\text { undocumented, which is } \\
\text { a requirement of the ISO } \\
14001 .\end{array}$ \\
\hline $\begin{array}{l}\text { The low score of this item } \\
\text { is justified by the informal } \\
\text { nature of the audits } \\
\text { occurred in the company to } \\
\text { date, having no legitimacy } \\
\text { for compliance with ISO } \\
14001 \text { requirements. }\end{array}$ \\
\hline Review \\
Mnternal Audit
\end{tabular}

As an immediate action, the recommendation is that the high administration appoints an internal audit to raise information on the non-compliances present in the company's EMS and the responsible area developer to propose the respective dealing actions for the maintenance of the management system.

Planning and execution of the improvements proposed by the company's sector responsible for the EMS together with the high administration and an internal audit schedule with qualified a consultant for an impartial evaluation of the environmental maturity of the company in its processes assessed by the ISO 14001 certification. For this FCS it is recommended that the internal audit results be evaluated and reviewed by the high administration to evaluate the functionality of the EMS.
The analysis of CSFs must be well based on the company's top management guidance for management priorities and resource allocation (QUINTELLA, 2009) required for implementation, adaptation and maintenance of the management system. The evaluation of economic viability, considering the company's revenues, says the sequential order of actions to be taken for it to improve its suitability percentages of the norm. As Table 7 presents the CSFs listed that do not require investments, but to change practices orders, requiring low, medium and high investment.

Table 7 - CSFs and their demands in investments.

\begin{tabular}{|l|}
\hline \multicolumn{1}{|c|}{ CSFs - NO INVESTMENT DEMAND } \\
\hline Environmental Policy \\
\hline Objectives and Goals \\
\hline Awareness and Training \\
\hline Communication \\
\hline Monitoring and Evaluation \\
\hline Preventive and Corrective Actions \\
\hline Environmental Management System Review \\
\hline \multicolumn{1}{c|}{ CSFs - LOW INVESTMENT DEMAND } \\
\hline Environmental Management Program \\
\hline Environmental Management System Documentation \\
\hline
\end{tabular}




\begin{tabular}{|l|}
\hline \multicolumn{2}{|c|}{ CSFs - MEDIUM INVESTMENT DEMAND } \\
\hline Specific Environmental Aspects \\
\hline Emergency Situations \\
\hline Internal Audit \\
\hline
\end{tabular}

The evaluation of the economic viability of CSFs was made taking into account the resources available by the high administration and listed in working with the representative of the administrative department.

Based on the results achieved in the diagnosis, it can be noted that both areas evaluated in the EMS and the QMS obtained an adequacy percentage superior to $70 \%$ (Table 8), score which can be justified by the fact that the company is already adapted to the requirements of the ISO 9001 norm, confirming the likelihood of a positive influence of the QMS already deployed in the SGA adaptation process.

Table 8 - Areas evaluated by QMS having obtained a good performance in the environmental assessment.

\begin{tabular}{cc}
\hline Areas & $\begin{array}{c}\text { Adequacy } \\
\text { (\%) }\end{array}$ \\
\hline Legal and Corporate Requirements & 76 \\
\hline $\begin{array}{c}\text { Organizational Structure and } \\
\text { Responsability }\end{array}$ & 75 \\
\hline Awareness and Training & 71 \\
\hline Document Control & 85 \\
\hline
\end{tabular}

For viewing and comparison, it is possible to observe the diagnosis results applied to the representative of the operational department (Table 9). The diagnoses obtained similarity between the Critical Success Factors (Table 10) with only minor variations in the adequacy percentages, and except for the item "Awareness and Training" that in the diagnosis applied to the operational sector representative was framed as a CSF because of its compliance degree of lower than $70 \%$. The discrepancy between the results at this point shows the functionality of the diagnosis that describes not only the compliance degree of the company's business processes with the ISO 14001 norm as well as different perceptions of space and activities when applied to more than one employee within the organization.

Table 9 - Environmental diagnosis result applied to the representative of the operating department.

\begin{tabular}{|l|l|}
\hline ITEMS OF MANAGEMENT SYSTEM & \multicolumn{2}{|l|}{ Overall Score: } \\
\hline ENVIRONMENTAL POLICY & $44 \%$ \\
\hline LEGAL AND CORPORATE REQUIREMENTS & $75 \%$ \\
\hline SPECIFIC ENVIRONMENTAL ASPECTS & $29 \%$ \\
\hline OBJECTIVES AND GOALS & $50 \%$ \\
\hline
\end{tabular}

\begin{tabular}{|l|c|}
\hline ENVIRONMENTAL MANAGEMENT PROGRAM & $29 \%$ \\
\hline ORGANIZATIONAL STRUCTURE AND RESPONSIBILITY & $79 \%$ \\
\hline AWARENESS AND TRAINING & $64 \%$ \\
\hline COMMUNICATION & $42 \%$ \\
\hline ENVIRONMENTAL MANAGEMENT SYSTEM & $34 \%$ \\
\hline DOCUMENTATION & $90 \%$ \\
\hline DOCUMENTATION CONTROL & $48 \%$ \\
\hline OPERATIONAL CONTROL & $29 \%$ \\
\hline EnergY consumption & $75 \%$ \\
\hline Wransport and Distribution & $28 \%$ \\
\hline Sanitary Sewage and Rainwater & $34 \%$ \\
\hline Industrial Effluents & $0 \%$ \\
\hline Waste Management & $70 \%$ \\
\hline Waste carriers and receivers & $69 \%$ \\
\hline Air Emission Management & $25 \%$ \\
\hline Noise & $38 \%$ \\
\hline Materials Management & $20 \%$ \\
\hline Production and Operating Processes & $56 \%$ \\
\hline Hygiene and Health & $98 \%$ \\
\hline EMERGENCY SITUATIONS & $55 \%$ \\
\hline MONITORING AND EVALUATION & $25 \%$ \\
\hline PREVENTIVE AND CORRECTIVE ACTIONS & $25 \%$ \\
\hline INTERNAL AUDIT & $2 \%$ RNIRONMENTAL MANAGEMENT SYSTEM REVIEW \\
\hline
\end{tabular}

In assessing the results obtained in both environmental diagnoses (Table 5 and 9), similar underperforming CSF numbers were obtained (Table 10), which have a direct relationship between them, as the demand for actions and maturity on an item influences on the performance of others, which points to a chronological hierarchy of actions demonstrated by the ISO norm in its own organization of content, which will help in the implementation process of the entire management system from the organization's Environmental Policy establishment to the Environmental Management System review of the already implanted. 
Brazilian Journal of Operations \& Production Management

Volume 13, Número 1, 2016, pp. 32-43

DOI: 10.14488/BJOPM.2016.v13.n1.a3

Table 10 - Critical Success Factors singled out by the results of diagnosis applied to the representatives of the administrative and operational department.

\begin{tabular}{ccc}
\hline CSFs & $\begin{array}{c}\text { Adequacy (\%) - } \\
\text { (administrative) diag. }\end{array}$ & $\begin{array}{c}\text { Adequacy (\%) - } \\
\text { (operational) diag. }\end{array}$ \\
\hline Environmental Policy & 38 & 44 \\
\hline Specific Environmental Aspects & 33 & 29 \\
\hline Objectives and Goals & 45 & 50 \\
\hline Environmental Management Program & 21 & 29 \\
\hline Communication & 48 & 42 \\
\hline Awareness and Training & - & 64 \\
\hline Environmental Management System \\
Documentation & 32 & 34 \\
\hline Operational Control & 50 & 48 \\
\hline Emergency Situations & 57 & 55 \\
\hline Monitoring and Evaluation & 25 & 25 \\
\hline Preventive and Corrective Actions & 39 & 32 \\
\hline Internal Audit & 33 & 25 \\
\hline Environmental Management System \\
Review
\end{tabular}

\section{FINAL CONSIDERATIONS}

The voluntary character of the EMS by the high administration connotes the company's positive social and environmental responsibility, which creates a favorable environmental image market. However, the increasing importance of implementing the Environmental Management System in the company is mainly related to the organization's legal compliance, primarily by the company's activities in the market, as a provider in the vector and pest control service industry, an activity considered as potentially polluting by IBAMA, which connotes its responsibility to society.

Among the limitations of the method identified in the study, it is possible to verify its difficult adaptation to a micro-enterprise context, since the model includes a wide range of areas, which in certain situations do not apply to its reality.

Another limitation is that the directory board has been the focus of the interviews, for the time required to search, which excludes observations that may contribute to the evaluation of the Critical Success Factors from the workforce point of view.

The last limitation identified in the study regards the application method of the chosen interviews. The diagnosis was applied in individual interviews, which limits the boost of discussions and exchange of ideas among all employees involved in the activity.
For further studies, it is suggested that the adaptation of the methodological model of initial environmental assessment for a context of micro and small businesses be done, in order to guarantee results as close to the reality of the organization as possible. The application of a diagnosis in two different methodologies, covering both the responses of a structured interview individually applied objectively, as well as application of diagnostic groups by area of the organization in a semi-structured way, to be allowed a greater interaction between the parts.

\section{BIBLIOGRAPHIC REFERENCES}

ABNT - Associação Brasileira de normas Técnicas. ISO 14001 - Sistema de Gestão Ambiental - Especificação e diretrizes para uso. ABNT, 1996.

ABNT/ISO - Associação Brasileira de normas Técnicas. ISO 14001 - Sistema de Gestão Ambiental - Especificação e diretrizes para uso. ABNT, 2004.

Agusti, A. L.; Deschamps, F.: Sistema de Gestão da Qualidade nas Micro e Pequenas Empresas. Revista Visão, v.2, n.1, p. 86-89. Santa Catarina, 2013.

Alperstedt, G. D; Quintella, R. H; Souza, L. R.: Estratégias de Gestão Ambiental e seus Fatores Determinantes: uma análise institucional, v. 50, n .2, 170-186 p. RAE. São Paulo, 2010. 
ANVISA. Resolução RDC no 52 - Serviço de Controle de Pragas. 2009. Disponível em <http://portal.anvisa.gov.br/ wps/wcm/connect/3ce8080047fe1a8abc40be9f306e0947/ RDC+52.2009.pdf?MOD=AJPERES>. Acesso em: 09 set. 2014, 17:38:00

Araújo, E. S; Borges, D.; Nascimento, A. A; Duarte, M. A. Análise Preliminar do Impacto do COMPERJ na Segurança Pública. Cadernos de Segurança Pública; ano IV, n. 3. ISP. Rio de Janeiro, 2012.

Barros, S. R. S.; Wasserman, J. C.; Alvim F. Diagnóstico de Avaliação do Sistema de Gestão Ambiental. Universidade Federal Fluminense. Niterói, 2009.

Bastos, A.; Matias, L. A.; , Kleberson E.; Damm, H.; Luna, M. M. M. Modelo Multicritério de Apoio a Decisão para Seleção de Fornecedores. Anais do VII Congresso Nacional de Excelência em Gestão. 12 a 13 de agosto de 2011. Disponível em <http://www.excelenciaemgestao.org/ portals/2/documents/cneg7/anais/t11_0379_1703.pdf.> Acesso em 08 set. 2014. 22:24:00.

D’Avignon, A. L. A. Sistemas de gestão ambiental e normalização ambiental. Segmento da apostila utilizada no curso sobre Auditorias Ambientais da Universidade Livre do Meio Ambiente. Curitiba: ULMA, 1996.

Domingues, F. COMPERJ, uma complexa equação. In: Macaé Offshore: A revista brasileira de petróleo e gás; Ano XI, n. 67, 2012.

Donaire, D. Gestão Ambiental na Empresa. 2a ed. São Paulo: Atlas, 1999.

Duarte, M. Apostila do Módulo Risco Ambiental. Rio de Janeiro, Master Bussines Environmental. - COPPE / UFRJ, 1999.

FEMAR - Fundação de Estudos do Mar, Curso Sistema de Gestão Ambiental. FEMAR, Apostila de curso - FDEPM Contrato no 52000-002/00 (DPC/ FEMAR), 2002.

Ferreira, M. C. Gestão Ambiental: práticas, condicionantes e evolução. Revista de Administração IMED, 2(2), p. 138150. Goiás, 2012.

Gomes, L. F. A. M; Gomes, C. F. S; Almeida, A. T. Tomada de decisão gerencial: Enfoque multicritério. São Paulo: Atlas. 2002. 264p.

González-Benito, J. G.; González-Benito, O. G. A review of determinant factors of environmental proactivity. Business Strategy and the Environment, v.15, p. 87-102, 2006.

IBAMA. Atividades Potencialmente Poluidoras e Utilizadoras de Recursos Ambientais. MMA, 2014. Disponível em <https://servicos.ibama.gov.br/index.php/ cadastro-inscricao-e-certidoes/cadastro-tecnico-federalde-atividades-potencialmente-poluidoras-eou-utilizadoras- de-recursos-ambientais-ctfapp>. Acesso em 20 ago. 2014, 20:30h.

ISO 14000: Edição atualizada e referências legais da versão 2004. São Paulo: INDG. 2007.

Jabbour, C. J. C.; Jabbour, A. B. L. S.; Stefanelli, N. O.; Teixeira, A. A. Gestão Ambiental e Estrutura Organizacional: estudo de múltiplos casos. REGE, v. 19, n. 3, p. 361-373. São Paulo, 2012.

Jabbour, C. J. C.; Teixeira, A. A.; Jabbour, A. B. L. de Souza; FREITAS, W. R. de S.. "Verdes e Competitivas?" A influência da Gestão Ambiental no Desempenho Operacional de Empresas Brasileira. Ambiente e Sociedade, ano XV, n. 2. São Paulo, 2012.

La Rovere, E. L. et al. Manual de Auditoria Ambiental. ed. Qualitymark: Rio de Janeiro; 17, 2001.

La Rovere, E. L. et al. Manual de Auditoria Ambiental. Rio de Janeiro, Qualitymark Editora. 2000. 140p.

Lee, K. H. Why and how to adopt green management into business organizations? The case study of Korean SMEs in manufacturing industry. Management Decision, v. 47, n. 7, 2009.

Leff, Enrique. Epistemologia Ambiental. São Paulo: Cortez Editora, 2000.

Machado da Silva, C. L; Fonseca, V. S; Fernandes, B. H. R. Mudança e estratégia nas organizações: perspectivas cognitiva e institucional. In: Vieira, M. M. F; Oliveira, L. M. B. Administração contemporânea: perspectivas estratégicas. São Paulo: Atlas, 1999.

Maekawa, R.; Carvalho, M. M; Oliveira, O. J. Um Estudo sobre a Certificação ISO 9001 no Brasil: mapeamento de motivações, benefícios e dificuldades. G \& P, v. 20, n. 4, p. 763-779. São Carlos, 2013.

Mattos, S. R. M. de. Análise Crítica da Aplicação do Sistema de Gestão Ambiental - ISO 14001 no Agronegócio na Região Metropolitana de Campinas. Dissertação de Mestrado apresentada à pós-graduação da Faculdade de Ciências Médicas. Universidade Estadual de Campinas. São Paulo, 2006.

Morioka, S. N. Análise de Fatores Críticos de Sucesso de Projetos em uma Empresa de Varejo. Trabalho de Conclusão de Curso apresentado à Escola Politécnica da Universidade de São Paulo. São Paulo, 2010.

Porto, M. F. de S.; Schütz, Gabriel E. Gestão Ambiental e Democracia: análise crítica, cenário e desafios. Ciência e Saúde Coletiva, 17(6):1447-1456. Rio de Janeiro, 2012.

Quintella, H. L. M. de M.; Lemos, R. G. F. de; Leitão, L. T. Fatores Críticos de Sucesso na Gestão Estratégica de Preços no Varejo: estudo comparativo das técnicas HILO e EDLP. 
Rio's Internacional Journal on Science of Industrial and Systems Engineering and Management. Universidade do Estado do Rio de Janeiro. Rio de Janeiro, 2009.

Rohrich, S. S; Cunha, J. C. A Proposição de uma taxonomia para análise da gestão ambiental no Brasil. Revista de Administração Contemporânea, v. 8, n. 4, 2004.

Silveira, M. P.; Alves, J. N. Sistema de Gestão Ambiental: Benefícios e Dificuldades. XV Mostra de Iniciação Científica. UNICRUZ, 2012.

Zucker, L. G. Normal change or risk business: institutional effects on the "hazard" of change in hospital organizations. Journal of Management Studies, v. 24, n. 6, p. 671-700, 1987. 